\title{
In vivo protein quality of new sorghum genotypes for human consumption
}

\author{
Érica Aguiar Moraes ${ }^{\mathrm{a}, *}$, Valéria Aparecida Vieira Queiroz ${ }^{\mathrm{b}}$, Robert Eugene Shaffert ${ }^{\mathrm{b}}$, \\ Neuza Maria Brunoro Costa ${ }^{\mathrm{c}}$, Julia D. Nelson ${ }^{\mathrm{d}, 1}$, Sônia Machado Rocha Ribeiro ${ }^{\mathrm{a}}$, \\ Hércia Stampini Duarte Martino ${ }^{a}$ \\ a Universidade Federal de Viçosa, Departamento de Nutrição e Saúde, Avenida PH Holfs, s/n Viçosa-MG, CEP: 36570-000, Brazil \\ ${ }^{\mathrm{b}}$ Embrapa Milho e Sorgo, Núcleo de Recursos Genéticos e Desenvolvimento de Cultivares, Rodovia MG 424, km 65, caixa postal 151, Sete Lagoas, MG, CEP: 35701-970, Brazil \\ ${ }^{\mathrm{c}}$ Universidade Federal do Espírito Santo, Departamento de Zootecnia, CCA-UFES, Alegre, ES, Brazil \\ ${ }^{\mathrm{d}}$ Texas AEM University, Department of Nutrition and Food Science, 122 Kleberg, 2253 TAMU College Station, TX 77843-2253, USA
}

\section{A R T I C L E I N F O}

\section{Article history:}

Received 8 November 2011

Received in revised form 1 March 2012

Accepted 20 March 2012

Available online 29 March 2012

\section{Keywords:}

Sorghum bicolor (L.) Moench

Amino acid profile

Digestibility

PDCAAS

Heat treatment

\begin{abstract}
A B S T R A C T
The in vivo protein qualities were evaluated in flours from raw sorghum grains (RF) and flours from sorghum grains subjected to heat treatment in an oven (HTF) from the hybrids BRS 305, BRS 309 and BRS 310, developed by the Brazilian Agricultural Research Corporation (Embrapa). There were no differences in feed efficiency ratios among experimental groups. Heat-treated flour from BRS 309 and BRS 310 genotypes had higher protein efficiency ratios and net protein ratio values; however, they did not differ from those of flour from raw grain of BRS 310 genotype. Effects of heat treatment were observed in the BRS 309 genotype. Heat treatment did not affect true digestibility observed for the RF and HTF of the three genotypes. Lysine was the first limiting amino acid of the three sorghum genotypes. The HTF BRS 305 showed the lowest protein digestibility-corrected amino acid score value. Heat treatment improved the protein quality of genotype BRS 309; however, no differences were observed among the other genotypes.
\end{abstract}

(c) 2012 Elsevier Ltd. All rights reserved.

\section{Introduction}

Sorghum (Sorghum bicolor (L.) Moench) is the largest source of calories and protein for millions of individuals, mainly in Africa and Asia (Dicko, Gruppen, Traoré, Voragen, \& Berkel, 2006; Mohammed, Mohamed, \& Babiker, 2010). It is used to make porridges, beverages, and bakery products, among other traditional foods (Anglani, 1998; Méndez-Albores et al., 2009; Sanchez, 2003).

The protein content of sorghum corresponds to approximately $11.3 \%$ of the grain (USDA, 2010). The quality of its proteins and its amino acid composition can vary widely, depending on both genetics and location of cultivation (Deyoe \& Shellenberger, 1965).

The protein quality of sorghum can be linked to phenolic compounds, such as tannins. These compounds are complexed to proteins, preventing their digestion and subsequent absorption (Dykes \& Rooney, 2006). Cyanogenic compounds, such as dhurrin, show toxic potential when hydrolyzed by their glucosidases (Morant et al., 2008) and could impair animal growth.

\footnotetext{
* Corresponding author.

E-mail address: erica_moraes12@hotmail.com (É.A. Moraes).

1 Address: 8007 Hydrangea Rd., Ore City, TX 75683, USA
}

Another determinant of the protein quality of the cereal is the technique of food processing. Cooking of sorghum for the production of porridge is the most commonly used preparation method (Duodu, Taylor, Belton, \& Hamaker, 2003). In vitro studies have shown that wet cooking reduces the digestibility of sorghum compared to other cereals (Hamaker, Kirleis, Mertz, \& Axtell, 1986; Mertz et al., 1984). According to some authors, the lower protein quality of this cereal (when cooked) is due to polymerization of the sorghum storage proteins, prolamins and kafirin, through the disulfide bond (Duodu et al., 2003; Hamaker et al., 1986), which also causes changes in protein secondary structure, from $\alpha$-helical to $\beta$-laminar (Emmambux \& Taylor, 2009). However, very few studies have investigated the effect of dry heat treatment on the quality of sorghum protein. Recently, Correia, Nunes, Barros, and Delgadillo (2010) observed (in an in vitro model) that thermal processing methods, such as wet cooking, reduce the digestibility of sorghum and that dry heat and extrusion do not result in alterations.

The feeding potential of sorghum, Embrapa Maize and Sorghum has stimulated research to characterize genotypes with superior technological and nutritional quality, aiming to encourage the use of sorghum for human consumption. The aim of this study was to evaluate the in vivo protein quality of flours from raw sorghum grains (RF) and flour from sorghum grains subjected to heat treatment in an oven (HTF). 
Table 1

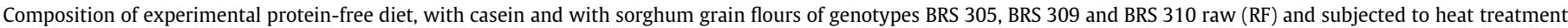
(HTF) (g $\left.100 \mathrm{~g}^{-1}\right)$.

\begin{tabular}{|c|c|c|c|c|c|c|c|c|}
\hline \multirow[t]{2}{*}{ Ingredients } & \multicolumn{8}{|c|}{ Experimental diets } \\
\hline & Protein-free & Casein & BRS 305 RF & BRS 305 HTF & BRS 309 RF & BRS 309 HTF & BRS 310 RF & BRS $310 \mathrm{HTF}$ \\
\hline BRS 305 RF & 0 & 0 & 89.0 & 0 & 0 & 0 & 0 & 0 \\
\hline BRS 305 HTF & 0 & 0 & 0 & 89.0 & 0 & 0 & 0 & 0 \\
\hline BRS 309 RF & 0 & 0 & 0 & 0 & 75.2 & 0 & 0 & 0 \\
\hline BRS 309 HTF & 0 & 0 & 0 & 0 & 0 & 75.2 & 0 & 0 \\
\hline BRS $310 \mathrm{RF}$ & 0 & 0 & 0 & 0 & 0 & 0 & 77.7 & 0 \\
\hline BRS 310 HTF & 0 & 0 & 0 & 0 & 0 & 0 & 0 & 77.7 \\
\hline Casein & 0 & 11 & 0 & 0 & 0 & 0 & 0 & 0 \\
\hline Maltodextrin & 13.2 & 12.5 & 0 & 0 & 9.4 & 9.4 & 7.7 & 7.7 \\
\hline Sucrose & 10 & 9.5 & 1.2 & 1.2 & 0 & 0 & 0 & 0 \\
\hline Soybean oil & 7 & 7 & 4.7 & 4.7 & 4.8 & 4.8 & 4.6 & 4.6 \\
\hline Cellulose & 10.2 & 10.2 & 0 & 0 & 3.3 & 3.3 & 2.6 & 2.6 \\
\hline Mineral mix & 3.5 & 3.5 & 3.5 & 3.5 & 3.5 & 3.5 & 3.5 & 3.5 \\
\hline Vitamin mix & 1 & 1 & 1 & 1 & 1 & 1 & 1 & 1 \\
\hline L-cystine & 0.3 & 0.3 & 0.3 & 0.3 & 0.3 & 0.3 & 0.3 & 0.3 \\
\hline Choline bitartrate & 0.25 & 0.25 & 0.25 & 0.25 & 0.25 & 0.25 & 0.25 & 0.25 \\
\hline Corn starch & 54.6 & 45.1 & 0.3 & 0.3 & 2.5 & 2.5 & 2.6 & 2.6 \\
\hline Total & 100.0 & 100.3 & 100.2 & 100.2 & 100.2 & 100.2 & 100.2 & 100.2 \\
\hline
\end{tabular}

\section{Material and methods}

\subsection{Sorghum genotype samples}

Three sorghum genotypes were analyzed in this study, all of them developed and supplied by Embrapa Maize and Sorghum, Sete Lagoas, MG, Brazil: BRS 305 (light brown pericarp, with testa), BRS 309 (white pericarp, without testa) and BRS 310 (red pericarp, without testa). The cultivation of sorghum genotypes was conducted using spacing between rows of $0.70 \mathrm{~m}$, mean density of 140,000 plants per hectare. Fertilization at sowing consisted of $300 \mathrm{~kg} \mathrm{ha}^{-1}$ of the $8-28-16$ NPK formula $+0.5 \% \mathrm{Zn}$. Other fertilization included $100 \mathrm{~kg} \mathrm{ha}^{-1}$ of urea, applied 40 days after germination. The planting was in Sete Lagoas, MG, Brazil, in February 2009.

\subsection{Flour preparation, and determination of total phenolic and condensed tannins of sorghum genotypes}

The sorghum grains were manually selected and sifted to remove dirt and impurities. To prepare the flours from grains subjected to heat treatment, the grains of the three sorghum genotypes were exposed to $105^{\circ} \mathrm{C}$ in an oven with air circulation (Nova Ética ${ }^{\circledR}$, model 400/6ND, Vargem Grande Paulista, São Paulo), as proposed by Souza et al. (2005), but modifying the exposure time to $30 \mathrm{~min}$. Afterwards, raw and heat-treated grains were ground with pericarp in a knife mill (C.W. Brasender ${ }^{\circledR}$, Dusburg, Germany) in order to obtain flour with a particle size of $850 \mu \mathrm{m}$.

Total phenolic content of the flours was determined, using the Folin-Ciocalteu method, as described by Singleton, Orthofer, Lamuela-Raventós and Lester (1999). The condensed tannins were measured, using the reaction vanillin/ $\mathrm{HCl}$, as described by Burns (1971) with modifications indicated by Maxson and Rooney (1972) and Price, Van Scoyoc, and Butler (1978).

\subsection{Biological assay}

Diet composition was based on guidelines from the American Institute of Nutrition for rodent growth (AIN-93G), according to Reeves, Nielsen, and Fahey (1993), with modification in the protein content to $9 \%$. The diets were homogenized in an industrial mixer $\left(\right.$ Lieme $^{\circledR}$ ). After preparation, the protein content was determined for each diet by the semimicro Kjeldahl method (928.08), according to AOAC (2002). The diets were packed in plastic bags, properly labelled and stored in a refrigerator at $5^{\circ} \mathrm{C}$.
All experimental diets were formulated to provide the same energy density. The cellulose concentration was changed to $10.2 \%$, depending on the fibre content of sorghum genotypes, to standardize the concentration of this nutrient among all diets (Table 1).

\subsection{Animals}

The experiment was carried out with forty-eight male rats (Rattus novergicus albinus, Rodentia mammalia), Wistar, recently weaned, 23 days of age and weighing 51-60 g, from the vivarium of the Center for Biological Sciences and Health, of the Federal University of Viçosa.

The animals were randomly divided into eight groups of six animals, so that the difference between mean weights did not exceed $2.2 \mathrm{~g}$, as recommended by AOAC (2002). The rats were kept in individual stainless steel cages and maintained at $22 \pm 3{ }^{\circ} \mathrm{C}$ with a $12 \mathrm{~h}$ light/dark cycle.

The animal groups were fed the following diets: protein-free diet, casein, and diets with flour from raw sorghum (RF) and flour from heat-treated grains (HTF) of the genotypes BRS 305, BRS 309 and BRS 310 (Table 1). During the 14 days, animals received the experimental diets and deionized water ad libitum.

The study protocol was approved by the Ethics Committee of the Veterinary Department, Federal University of Viçosa, Brazil (Protocol n $\left.{ }^{\circ} 28 / 2010\right)$.

\subsection{Feed efficiency ratio}

During the experimental period, animals were weighed on the 1st, 7th and 14th days and the feed efficiency ratio (FER) was determined, which represents the relationship between weight gain $(\mathrm{g})$ and dietary intake by the animals $(\mathrm{g})$.

\subsection{Protein efficiency ratio and net protein ratio}

The protein efficiency ratio (PER) was determined by the Hegsted method (1977), which relates the weight gain of animals ( $g$ ) with the protein intake $(\mathrm{g})$, modified for 14 days of experiment. The relative protein efficiency ratio (R-PER) was determined with the PER result of a casein diet established at $100 \%$.Net protein ratio (NPR) was calculated according to Bender and Doell (1957), taking into account the weight gain of test group (W) and the weight loss of the protein-free diet group (WL) in relation to the test group's protein consumption (PC), according to the formula: 
$\mathrm{NPR}=\frac{\mathrm{W}(\mathrm{g})+\mathrm{WL}(\mathrm{g})}{\mathrm{PC}(\mathrm{g})}$

The relative net protein ratio (R-NPR) was determined considering the NPR result of a casein diet as $100 \%$.

\subsection{True digestibility}

In order to determine the true digestibility (TD), diets were stained with $0.2 \%$ indigo carmine dye. These diets were offered to animals on the 8 th and 11 th days. The stained feces were collected on the 9th day, as well as all the feces at the 10th and 11 th days and the unstained feces on the 12th day. The feces collected were stored in individual containers for each animal and kept under refrigeration. Subsequently, the feces were dried in an oven (Marconi ${ }^{\circledR}$, model MA 035, Piracicaba, Brazil) at $105^{\circ} \mathrm{C}$ for $24 \mathrm{~h}$, then they were cooled, weighed and crushed in a multiprocessor $\left(\right.$ Arno $\left.^{\circledR}\right)$ for determining the nitrogen concentration by the semimicro Kjeldahl method (928.08) (AOAC, 2002), with samples in triplicate.

TD was calculated by measuring the amount of nitrogen ingested (I) and excreted in feces in the test diet groups $(\mathrm{F})$ and nitrogen fecal loss of the protein-free diet group (Fk) according to the formula: $\% \mathrm{TD}=\mathrm{I}-(\mathrm{F}-\mathrm{Fk})$.

\subsection{Amino acid composition}

Total lipids of sorghum flours were extracted with petroleum ether in a Soxhlet apparatus (Method 960.39) according AOAC (2002). The defatted sorghum flours were hydrolyzed in $6 \mathrm{M}$ hydrochloric acid containing $0.1 \%$ phenol for $22 \mathrm{~h}$ at $110 \pm 1{ }^{\circ} \mathrm{C}$ and in $4 \mathrm{M}$ lithium hydroxide for $24 \mathrm{~h}$ at the same temperature to quantify tryptophan. Amino acid analysis was performed by ion-exchange chromatography on a sulfonated polystyrene-divinylbenzene copolymer resin, with post-column derivatization with ninhydrin, as described by Spackman, Stein, and Moore (1958), using an automated analyzer (Alonzo \& Hirs, 1968) built at the Protein Chemistry Center, Faculty of Medicine of Ribeirão Preto, University of São Paulo. This amino acid analyzer consists basically of two ion exchange columns, a long column $(0.9 \times 30 \mathrm{~cm})$ that separates acidic and neutral amino acids and a short column $(0.9 \times 15 \mathrm{~cm})$ that separates basic amino acids and tryptophan. The separation is based on a $0.2 \mathrm{M}$ sodium citrate temperature step gradient in long column $\left(\mathrm{pH} 3.25\right.$ and $\mathrm{pH} 4.25$, at $50{ }^{\circ} \mathrm{C}$ ) and $0.37 \mathrm{M}$ sodium citrate $(\mathrm{pH} 5.28$ and $50{ }^{\circ} \mathrm{C}$ ) in short column. The flow rate was $0.6 \mathrm{ml} / \mathrm{min}$ for citrate buffers and $0.3 \mathrm{ml} / \mathrm{min}$ for ninhydrin. Amino acids eluted from columns were detected by reaction with ninhydrin, and quantified by colorimetry at $440 \mathrm{~nm}$ for proline and $570 \mathrm{~nm}$ for other amino acids. Amino acid identification was achieved, based on the elution volume of each residue, compared to a standard amino acid solution (Pierce H, Rockford, Illinois) containing $40 \mathrm{nmol}$ of each amino acid chromatographed under the same conditions. The quantification was performed using the peak height of the standard, which was used to calculate the factor (concentration/peak height). Amino acid composition was presented as $\mathrm{g} 100 \mathrm{~g}^{-1}$ of dry sample.

The amino acid composition and subsequent calculation of chemical score and chemical score corrected by digestibility were determined in heat-treated sorghum flours at $105^{\circ} \mathrm{C}$ for $30 \mathrm{~min}$.

\subsection{Amino acid score and protein digestibility-corrected amino acid score}

To calculate amino acid score (AAS) and the protein digestibility-corrected amino acid score (PDCAAS), the amino acid content values were expressed as milligrammes of amino acid per gramme of protein and compared with those of the World Health Organization (WHO, 2007). The obtained data were used in the determination of nitrogen, protein, essential amino acids, amino acid score and true digestibility.

The calculation of PDCAAS took (as basis) the amino acid score value of the most limiting essential amino acid (AAS lower than 1.0) of each protein source. PDCAAS was calculated by multiplying the essential amino acid lowest score by the true digestibility of protein. Protein with PDCAAS $\geqslant 100$ was considered of good quality (Henley \& Kuster, 1994).

\subsection{Statistical analysis}

Experimental treatments were arranged in blocks of six repetitions, so that the average initial weights of animals were similar.

The results were analyzed by ANOVA $(\alpha=5 \%)$. For significant " $F$ ", the post hoc Dunnett test, at 5\% probability, was used to compare each test group with casein group (control). Duncan's test was performed with a probability of $5 \%$ in order to compare the averages achieved when evaluating the effect of heat treatment, both on protein quality of raw and heat-treated sorghum flours and on the amino acid content and PDCAAS of flours undergoing treatment. The mean dispersion was expressed as standard deviation.

Statistical analysis was performed using the SAEG programme for statistical analysis, version 9.1, licensed for use by the Federal University of Viçosa, MG.

\section{Results and discussion}

\subsection{Total phenolic and condensed tannin}

Heat treatment increased the total phenolic content by approximately $50 \%$ and the concentration of condensed tannins by $12 \%$ in flour of the BRS 305 genotype $(p<0.05)$ (Table 2$)$. High concentrations of these compounds in the BRS 305 genotype can be due to the presence of pigmented testa (Dykes, Rooney, Waniska, \& Rooney, 2005). In heat-treated sorghum genotype BRS 309 flour, reduction in the concentration of condensed tannins was observed $(p<0.05)$ (Table 2).

\subsection{Feed efficiency ratio}

The diets were isocaloric and isoproteic, ranging between 3.0 and $3.8 \mathrm{kcal} \mathrm{g}^{-1}$ and between $9.0 \%$ and 9.9\% $(p \geqslant 0.05)$, respectively, as planned (Table 3). There was no difference in FER between the casein and test groups, nor between groups fed by raw and heat-treated flour diets $(p \geqslant 0.05)$. The similarity between

\section{Table 2}

Total phenolic (TP) and condensed tannins (CT) of sorghum grain flours of genotypes BRS 305, BRS 309 and BRS 310 raw (RF) and subjected to heat treatment (HTF).

\begin{tabular}{lll}
\hline Sorghum flours & $\mathrm{TP} \pm \mathrm{SD}$ & $\mathrm{CT} \pm \mathrm{SD}$ \\
\hline BRS 305 RF & $4.50^{\mathrm{b}} \pm 0.19$ & $59.5^{\mathrm{b}} \pm 0.39$ \\
BRS 305 HTF & $6.82^{\mathrm{a}} \pm 0.35$ & $66.9^{\mathrm{a}} \pm 1.71$ \\
BRS 309 RF & $0.72^{\mathrm{c}} \pm 0.00$ & $12.5^{\mathrm{c}} \pm 0.53$ \\
BRS 309 HTF & $0.84^{\mathrm{c}} \pm 0.00$ & $2.90^{\mathrm{d}} \pm 0.13$ \\
BRS 310 RF & $0.68^{\mathrm{c}} \pm 0.00$ & $11.6^{\mathrm{c}} \pm 1.04$ \\
BRS 310 HTF & $0.95^{\mathrm{c}} \pm 0.11$ & $12.5^{\mathrm{c}} \pm 2.04$ \\
\hline
\end{tabular}

$\mathrm{SD}=$ Standard deviation

The TP content was expressed in milligrammes of equivalents of gallic acid per gramme of sample $\left(\mathrm{mgEAG}^{-1}\right)$.

The CT was expressed in milligrammes of catechin per gramme of sample $\left(\mathrm{mgEC}^{-1}\right)$.

Means followed by the same small letters in columns do not differ from each other according to the Duncan test $(p<0.05)$, to compare the effect of raw and heattreated sorghum flours. 
Table 3

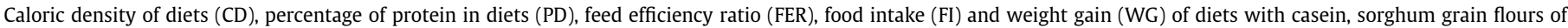
genotypes BRS 305, BRS 309 and BRS 310 raw (RF) and subjected to heat treatment (HTF).

\begin{tabular}{|c|c|c|c|c|c|}
\hline Diet & $\mathrm{CD}$ & $\mathrm{PD}+\mathrm{SD}(\%) *$ & $\mathrm{FER}+\mathrm{SD} * *$ & $\mathrm{FI}+\mathrm{SD}(\mathrm{g})$ & $W G+S D(g)$ \\
\hline Casein & 3.8 & $9.0^{\mathrm{A}} \pm 0.45$ & $0.26^{\mathrm{A}} \pm 0.03$ & $151.87^{\mathrm{A}} \pm 17.78$ & $39.33^{\mathrm{A}} \pm 8.45$ \\
\hline BRS 305 RF & 3.0 & $9.5^{\mathrm{A}} \pm 0.69$ & $0.05^{\mathrm{Aa}} \pm 0.01$ & $100.69^{\mathrm{Ba}} \pm 6.03$ & $4.66^{\mathrm{Bbc}} \pm 1.63$ \\
\hline BRS 305 HTF & 3.0 & $9.5^{\mathrm{A}} \pm 0.05$ & $0.03^{\mathrm{Aa}} \pm 0.02$ & $89.54^{\mathrm{Ba}} \pm 10.00$ & $3.00^{\mathrm{Bc}} \pm 2.28$ \\
\hline BRS 309 RF & 3.4 & $8.8^{\mathrm{A}} \pm 0.09$ & $0.05^{\mathrm{Aa}} \pm 0.02$ & $96.50^{\mathrm{Ba}} \pm 5.59$ & $5.00^{\mathrm{Bbc}} \pm 2.66$ \\
\hline BRS 309 HTF & 3.4 & $9.3^{\mathrm{A}} \pm 0.08$ & $0.10^{\mathrm{Aa}} \pm 0.02$ & $97.58^{\mathrm{Ba}} \pm 7.20$ & $9.66^{\mathrm{Ba}} \pm 2.25$ \\
\hline BRS 310 RF & 3.3 & $9.3^{\mathrm{A}} \pm 0.78$ & $0.08^{\mathrm{Aa}} \pm 0.05$ & $104.19^{\mathrm{Ba}} \pm 18.79$ & $8.50^{\mathrm{Bab}} \pm 5.79$ \\
\hline BRS 310 HTF & 3.3 & $9.9^{A} \pm 0.22$ & $0.09^{\mathrm{Aa}} \pm 0.02$ & $103.42^{\mathrm{Ba}} \pm 12.37$ & $10.00^{\mathrm{Ba}} \pm 3.03$ \\
\hline
\end{tabular}

$\mathrm{SD}=$ Standard deviation

Means do not differ from each other according to ANOVA * $(p=0.317)^{* *}(p=0.059)$;

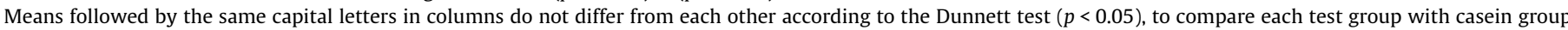
(control).

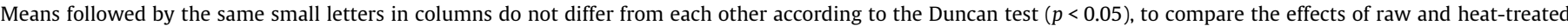
sorghum flours among test groups.

the FER values indicated that diets were isocaloric and the weight gain difference was due to protein quality of raw materials (Table 3).

Food intake and body weight gain of casein-fed animals were higher in relation to test groups $(p<0.05)$. The quality of the standard protein (animal origin) and the proteins from test diets (vegetable origin) justifies the differences between parameters (Table 3).

The heat treatment did not affect food intake in groups fed flours from raw and heat-treated grain diets $(p \geqslant 0.05)$. However, the weight gain in the animals fed flour from heat-treated grains of BRS 309 genotype was approximately twice higher than that in the animals fed on raw grain flour of the same genotype $(p<0.05)$. The treatment had no effect on the weight gain of animals fed flours from raw and heat-treated grains of genotypes BRS 305 and BRS 310 ( $p \geqslant 0.05$ ) (Table 3 ).

\subsection{Protein efficiency ratio and net protein ratio}

The PER and NPR of the casein-fed animals were higher than those of the experimental groups $(p<0.05)$ as indicated by animal weight gain (Table 4).

Heat-treated flours from the BRS 309 and BRS 310 genotypes had higher PER and NPR values; however, they did not differ from raw grain flour of the BRS 310 genotype $(p \geqslant 0.05)$. Heat treatment affected the biological significance of the BRS 309 genotype. Heattreated flour from BRS 309 had higher PER and NPR values than had the raw flour $(p<0.05)$ (Table 4$)$.

The improvement of biological indices of heat-treated flour from the BRS 309 genotype might be attributed to the denaturation/inactivation of the $\beta$-glucosidase, dhurrinase 1 . This genotype was developed from the intersection of lineage sorghum CMSXS
182 that contains the cyanogenic compound dhurrin, and it continues to display this compound in its content (Prates et al., 1998). In monocotyledons, such as sorghum, the enzyme substrate, dhurrin, is stored exclusively in the epidermal layer of the cells, while its $\beta$ glucosidase is stored in the chloroplasts. Thus, when plant tissue is disrupted, as in the present study, in order to obtain sorghum flour, substrate hydrolysis releases toxic hydrogen cyanide (HCN) (Morant et al., 2008). However, the exposure of raw grains to heat before milling may have inactivated the enzyme action and prevented the HCN formation (Márquez \& Waliszewski, 2008).

The PER and NPR values found in the flour from raw grains of the BRS 309 genotype were similar to those found in the flours from both raw and heat-treated grains of the BRS 305 genotype $(p \geqslant 0.05)$. These results might be explained by the formation of $\mathrm{HCN}$ in the flour from raw grains of the BRS 309 genotype. The short period of the experiment can prevent the animals from suffering the toxic effect of this compound, though its presence may have caused the lowest weight gain, as reflected in the analyzed biological indicators. In the BRS 305 genotype, this result is due to the high concentrations of the condensed tannins, which increased by $12 \%$ with the heat treatment. Neither the use nor the cultivation of sorghum genotypes with dhurrin is rare, since these are more resistant to bird attacks (Prates et al., 1998). Given the results in this paper, additional studies are necessary on the dhurrin toxic action and its antinutritional effect on biological growth parameters, and also on the heat treatment effect on this compound, since sorghum with these characteristics may currently be used without full comprehension of its negative effects.

The PER value ranged between 0.35 and 1.06 for heat-treated flour from genotypes BRS 305 and BRS 309, respectively. According to Friedman and Gumbmann (1986), protein sources with PER values lower than 1.5 are of poor quality; thus, sorghum protein can

Table 4

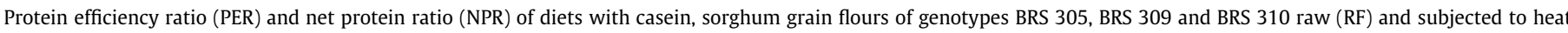
treatment (HTF)

\begin{tabular}{|c|c|c|c|c|}
\hline Diet & PER + SD & R-PER + SD (\%) & $\mathrm{NPR}+\mathrm{SD}$ & R-NPR + SD (\%) \\
\hline Casein & $2.87^{\mathrm{A}} \pm 0.33$ & 1000 & $3.44^{\mathrm{A}} \pm 0.29$ & 100 \\
\hline BRS 305 RF & $0.49^{\mathrm{Bbc}} \pm 0.15$ & 17.0 & $1.30^{\mathrm{Bc}} \pm 0.13$ & 37.7 \\
\hline BRS 305 HTF & $0.35^{\mathrm{Bc}} \pm 0.28$ & 12.1 & $1.28^{\mathrm{Bc}} \pm 0.23$ & 37.3 \\
\hline BRS 309 RF & $0.58^{\mathrm{Bbc}} \pm 0.26$ & 17.4 & $1.49^{\mathrm{Bbc}} \pm 0.22$ & 43.4 \\
\hline BRS 309 HTF & $1.06^{\mathrm{Ba}} \pm 0.23$ & 37.2 & $1.91^{\mathrm{Ba}} \pm 0.23$ & 55.7 \\
\hline BRS 310 RF & $0.83^{\mathrm{Bab}} \pm 0.49$ & 29.1 & $1.64^{\mathrm{Bab}} \pm 0.42$ & 48.0 \\
\hline BRS 310 HTF & $0.98^{\mathrm{Ba}} \pm 0.21$ & 34.3 & $1.76^{\mathrm{Bab}} \pm 0.14$ & 51.3 \\
\hline
\end{tabular}

$\mathrm{SD}=$ Standard deviation

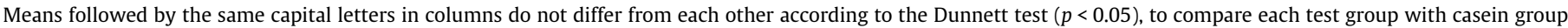
(control).

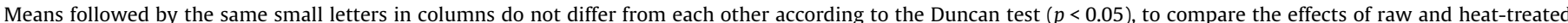
sorghum flours among test groups. 
be classified as a low-quality protein. Although sorghum has a lowquality protein, the application of heat treatment to grain increased the values of biological indices, especially for genotype BRS 309.

Comparing PER values of sorghum and other cereals, the heattreated flours of genotypes BRS 309 and BRS 310 had PER values similar to those of animals fed with wheat flour (0.98), which is higher than the value obtained for animals fed with corn meal (0.68) (Pires, Oliveira, Rosa, \& Costa, 2006) and lower than for those fed with rice (2.57) and quinoa (2.13) (Mendes, Oliveira, Costa, Pires, \& Hoffmam, 2009). Higher NPR values were presented by corn meal (3.89), wheat flour (2.38), rice (3.62) and quinoa (3.68) when compared to all sorghum genotypes (Mendes et al., 2009; Pires et al., 2006).

\subsection{True digestibility}

The nitrogen intake was higher in the casein group than in the test group $(p<0.05)$. Among the groups that received flours from raw and heat-treated grains, there were no differences in nitrogen intake levels $(p \geqslant 0.05)$. However, the fecal nitrogen excretion was higher in animals fed flours from both raw and heat-treated grains of genotype BRS 305, both in relation to the control group and test diets $(p<0.05)$ (Table 5$)$.

Among the groups that received flours from raw and heat-treated grains, both nitrogen consumption and its excretion by the animals were similar, except for both groups of the BRS 305 genotype, which showed higher excretion of nitrogen. This may be associated with the presence of tannins in genotype BRS 305, which agrees with Al-Mamary, Molham, Abdulwali, and Al-Obeidi (2001), who reported that the increased nitrogen excretion by animals fed on high tannin sorghum is caused by the impaired protein digestion plus the interaction between the tannins and the intestinal mucus glycoproteins.

True digestibilities of flours from raw and heat-treated grains of BRS 309 and BRS 310 genotypes were similar to that of casein (control) $(p \geqslant 0.05)$. However, the flours from raw and heat-treated grains of BRS 305 showed lower digestibility than did the control and test diet groups $(p<0.05)$. The heat treatment made no difference to the true digestibility between raw and heat-treated flours $(p \geqslant 0.05)$ (Table 5). Correia et al. (2010) also found that sorghum flours, treated in a water bath for $90 \mathrm{~min}$, do not alter the digestibility in vitro compared to non-processed flours.

The true digestibility similarity (between casein and both raw and heat-treated flours from BRS 309 and BRS 310 genotypes) indicated that the proteins of sorghum were properly hydrolyzed by the digestive enzymes, not being affected by the first factor that alters the efficiency of protein utilization (Friedman \& Gumbmann, 1986). However, these sorghum genotypes were classified as low-quality protein, due to the low PER values; therefore, they were not suitable for promoting growth and development of animals. In this study, there was probably a high retention of nitrogen from non-essential sources, which possibly led to imbalance in the supply of essential amino acids, affecting the quality of sorghum protein.

All sorghum varieties showed higher digestibility than did corn meal (82\%) (Pires et al., 2006). With the exception of the BRS 305 genotype, both with and without heat treatment, the other genotypes showed higher digestibilities than did wheat (89\%) and quinoa (85\%) (Mendes et al., 2009; Pires et al., 2006).

\subsection{Amino acid composition}

The BRS 310 heat-treated flours showed higher concentrations of cysteine, phenylalanine, threonine, tyrosine, glutamic acid, glycine, proline and serine $(p<0.05)$. The concentrations of isoleucine,
Table 5

Nitrogen intake (NI), nitrogen excretion (NE) and true digestibility (TD) of diets with casein, sorghum grain flours of genotypes BRS 305, BRS 309 and BRS 310 raw (RF) and subjected to heat treatment (HTF).

\begin{tabular}{lccc}
\hline Diet & $\mathrm{NI}+\mathrm{SD}(\mathrm{g})$ & $\mathrm{NE}+\mathrm{SD}(\mathrm{g})$ & $\mathrm{TD}+\mathrm{SD}$ \\
\hline Casein & $0.53^{\mathrm{A}} \pm 0.05$ & $0.28^{\mathrm{A}} \pm 0.01$ & $93.9^{\mathrm{A}} \pm 1.88$ \\
BRS 305 RF & $0.31^{\mathrm{Ba}} \pm 0.02$ & $0.79^{\mathrm{Ba}} \pm 0.01$ & $63.4^{\mathrm{Bb}} \pm 6.03$ \\
BRS 305 HTF & $0.28^{\mathrm{Ba}} \pm 0.04$ & $0.81^{\mathrm{Ba}} \pm 0.02$ & $57.6^{\mathrm{Bb}} \pm 7.22$ \\
BRS 309 RF & $0.30^{\mathrm{Ba}} \pm 0.03$ & $0.32^{\mathrm{Ab}} \pm 0.01$ & $87.6^{\mathrm{Aa}} \pm 4.00$ \\
BRS 309 HTF & $0.32^{\mathrm{Ba}} \pm 0.03$ & $0.35^{\mathrm{Ab}} \pm 0.01$ & $86.7^{\mathrm{Aa}} \pm 4.09$ \\
BRS 310 RF & $0.33^{\mathrm{Ba}} \pm 0.06$ & $0.37^{\mathrm{Ab}} \pm 0.02$ & $86.4^{\mathrm{Aa}} \pm 7.08$ \\
BRS 310 HTF & $0.34^{\mathrm{Ba}} \pm 0.05$ & $0.37^{\mathrm{Ab}} \pm 0.02$ & $86.7^{\mathrm{Aa}} \pm 2.71$ \\
\hline
\end{tabular}

$\mathrm{SD}=$ Standard deviation.

Means followed by the same capital letters in columns do not differ from each other according to the Dunnett test $(p<0.05)$, to compare each test group with casein group (control)

Means followed by the same small letters in columns do not differ from each other according to the Duncan test $(p<0.05)$, to compare the effects of raw and heattreated sorghum flours among test groups.

leucine, aspartic acid and valine were similar between BRS 310 and BRS 309 genotypes $(p \geqslant 0.05)$. The BRS 305 showed low concentrations of essential amino acids when compared to others $(p<0.05)$, and this fact, along with the presence of tannins and the increased excretion of fecal nitrogen, explains the lower weight gain in this experimental group (Table 6).

\subsection{Amino acid score and protein digestibility-corrected amino acid} score

In heat-treated flours the limiting essential amino acids were lysine, isoleucine, cystine, methionine, valine and threonine (except BRS 310). Lysine was the first limiting amino acid, due to the lowest amino acid score found for it. However, Mokrane et al. (2010) found that, among five sorghum cultivars tested, only three essential amino acids were limiting: lysine, methionine and cysteine. It is noteworthy that the amino acid concentrations might vary widely, depending on the influence of sorghum genetics and planting location (Deyoe \& Shellenberger, 1965) (Table 7).

Table 6

Amino acid contents (g/100 g) of sorghum grain flours of genotypes BRS 305, BRS 309 and BRS 310 subjected to heat treatment $\left(105^{\circ} \mathrm{C} / 30 \mathrm{~min}\right)$.

\begin{tabular}{|c|c|c|c|}
\hline \multirow[t]{2}{*}{ Amino acids } & \multicolumn{3}{|l|}{ Sorghum genotypes } \\
\hline & BRS $305 \mathrm{HTF}+\mathrm{SD}$ & BRS $309 \mathrm{HTF}+\mathrm{SD}$ & BRS $310 \mathrm{HTF}+\mathrm{SD}$ \\
\hline \multicolumn{4}{|l|}{ Indispensable } \\
\hline $1 / 2$ Cystine & $0.09^{c} \pm 0.00$ & $0.10^{\mathrm{b}} \pm 0.00$ & $0.1^{\mathrm{a}} \pm 0.00$ \\
\hline Histidine & $0.23^{\mathrm{b}} \pm 0.00$ & $0.32^{\mathrm{a}} \pm 0.00$ & $0.32^{\mathrm{a}} \pm 0.01$ \\
\hline Isoleucine & $0.21^{b} \pm 0.00$ & $0.29^{\mathrm{a}} \pm 0.00$ & $0.30^{\mathrm{a}} \pm 0.01$ \\
\hline Leucine & $0.77^{\mathrm{b}} \pm 0.01$ & $1.08^{a} \pm 0.01$ & $1.10^{\mathrm{a}} \pm 0.01$ \\
\hline Lysine & $0.20^{\mathrm{C}} \pm 0.00$ & $0.31^{\mathrm{a}} \pm 0.00$ & $0.26^{\mathrm{b}} \pm 0.02$ \\
\hline Methionine & $0.13^{\mathrm{a}} \pm 0.00$ & $0.14^{\mathrm{a}} \pm 0.00$ & $0.13^{\mathrm{a}} \pm 0.01$ \\
\hline Phenylalanine & $0.34^{\mathrm{c}} \pm 0.0$ & $0.43^{\mathrm{b}} \pm 0.01$ & $0.49^{\mathrm{a}} \pm 0.00$ \\
\hline Threonine & $0.25^{\mathrm{c}} \pm 0.02$ & $0.31^{\mathrm{b}} \pm 0.01$ & $0.34^{\mathrm{a}} \pm 0.00$ \\
\hline Tryptophan & $0.09^{c} \pm 0.00$ & $0.17^{\mathrm{a}} \pm 0.00$ & $0.16^{\mathrm{b}} \pm 0.00$ \\
\hline Tyrosine & $0.24^{\mathrm{c}} \pm 0.01$ & $0.27^{\mathrm{b}} \pm 0.01$ & $0.34^{\mathrm{a}} \pm 0.00$ \\
\hline Valine & $0.26^{\mathrm{b}} \pm 0.00$ & $0.35^{\mathrm{a}} \pm 0.01$ & $0.36^{\mathrm{a}} \pm 0.01$ \\
\hline Total & 2.81 & 3.77 & 3.91 \\
\hline \multicolumn{4}{|l|}{ Dispensable } \\
\hline Alanine & $0.55^{\mathrm{b}} \pm 0.01$ & $0.76^{\mathrm{a}} \pm 0.01$ & $0.75^{\mathrm{a}} \pm 0.00$ \\
\hline Arginine & $0.28^{\mathrm{c}} \pm 0.00$ & $0.46^{\mathrm{a}} \pm 0.00$ & $0.36^{\mathrm{b}} \pm 0.01$ \\
\hline Aspartic acid & $0.48^{\mathrm{b}} \pm 0.00$ & $0.67^{a} \pm 0.01$ & $0.70^{\mathrm{a}} \pm 0.01$ \\
\hline Glutamic acid & $1.18^{\mathrm{c}} \pm 0.01$ & $1.56^{\mathrm{b}} \pm 0.01$ & $1.65^{\mathrm{a}} \pm 0.05$ \\
\hline Glycine & $0.23^{\mathrm{c}} \pm 0.00$ & $0.27^{\mathrm{b}} \pm 0.00$ & $0.29^{\mathrm{a}} \pm 0.01$ \\
\hline Proline & $0.60^{c} \pm 0.00$ & $0.67^{\mathrm{b}} \pm 0.00$ & $0.77^{\mathrm{a}} \pm 0.01$ \\
\hline Serine & $0.32^{c} \pm 0.00$ & $0.39^{\mathrm{b}} \pm 0.00$ & $0.45^{\mathrm{a}} \pm 0.00$ \\
\hline Total & 3.64 & 4.78 & 4.97 \\
\hline
\end{tabular}

$\mathrm{SD}=$ Standard deviation

Means followed by the same letters in lines do not differ from each other according to the Duncan test $(p<0.05)$. 
Table 7

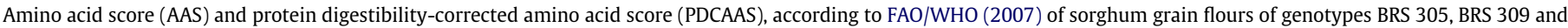
BRS 310 subjected to heat treatment $\left(105^{\circ} \mathrm{C} / 30 \mathrm{~min}\right)$.

\begin{tabular}{|c|c|c|c|c|c|c|c|c|c|c|}
\hline \multirow[t]{2}{*}{ Essential amino acids } & \multicolumn{3}{|l|}{ BRS 305 HTF } & \multicolumn{3}{|l|}{ BRS 309 HTF } & \multicolumn{4}{|l|}{ BRS $310 \mathrm{HTF}$} \\
\hline & mg aa/g ptn & AAS & PDCAAS + SD & mg aa/g ptn & AAS & $\mathrm{PDCAAS}+\mathrm{SD}$ & mg aa/g ptn & ASS & PDCAAS + SD & WHO (2007) \\
\hline Tryptophan & 9.43 & 1.27 & $33.4^{\mathrm{b}} \pm 0.57$ & 14.3 & 1.92 & $47.0^{\mathrm{a}} \pm 0.65$ & 14.1 & 1.90 & $42.4^{\mathrm{a}} \pm 2.70$ & 7.4 \\
\hline Lysine & 20.2 & 0.38 & & 25.7 & 0.49 & & 22.7 & 0.43 & & 52.0 \\
\hline Histidine & 23.3 & 1.29 & & 26.6 & 1.47 & & 27.3 & 1.51 & & 18.0 \\
\hline Threonine & 24.6 & 0.91 & & 25.9 & 0.95 & & 29.3 & 1.08 & & 27.0 \\
\hline $1 / 2$ Cystine + methionine & 22.1 & 0.84 & & 20.4 & 0.78 & & 21.3 & 0.81 & & 26.0 \\
\hline Valine & 25.3 & 0.60 & & 28.9 & 0.68 & & 31.0 & 0.73 & & 42.0 \\
\hline Isoleucine & 21.0 & 0.67 & & 24.5 & 0.78 & & 26.0 & 0.83 & & 31.0 \\
\hline Leucine & 76.3 & 1.21 & & 90.2 & 1.43 & & 94.9 & 1.50 & & 63.0 \\
\hline Tyrosine + phenylalanine & 56.7 & 1.23 & & 58.7 & 1.27 & & 71.7 & 1.55 & & 46.0 \\
\hline
\end{tabular}

$\mathrm{SD}=$ Standard deviation.

$\mathrm{mg} \mathrm{aa} / \mathrm{g}$ ptn = milligrammes of amino acids per gramme of proteins

Means followed by the same letters in lines do not differ from each other according to the Duncan test $(p<0.05)$.

Comparing the amino acid scores of sorghum and other cereals (Pires et al., 2006), it was shown that wheat and corn are deficient in these amino acids and also have lysine as the first limiting amino acid (Onyango, Noetzold, Bley, \& Henle, 2004).

PDCAAS values ranged between $33 \%$ and $46 \%$ for genotypes BRS 305 and BRS 309, respectively. The PDCAAS values obtained for BRS 309 and BRS 310 were similar $(p \geqslant 0.05)$. Therefore, it is possible to conclude that the proteins of the analyzed sorghum genotypes are of low quality since they have PDCAAS values lower than $50 \%$. Sorghum genotypes showed PDCAAS values similar to those of other cereals, such as corn (37\%) and wheat (40\%) (Pires et al., 2006).

In the in vitro model of raw sorghum flour, PDCAAS values ranged between $6 \%$ and $20 \%$, considering lysine as the first limiting amino acid, which is approximately twice smaller than the values obtained in this study (Mokrane et al., 2010).

\section{Conclusion}

Heat treatment improved the protein quality of the BRS 309 genotype, with dhurrin and without tannins, by doubling the PER value.

The amino acid profile of sorghum was the main limitation of protein quality because, although the true digestibility of sorghum, with and without heat treatment and without tannin, was high, the growth of animals was inadequate.

Though the sorghums showed low quality protein contents, the values were similar and sometimes higher than those found in other grains, which indicates that their replacement by sorghum does not lead to losses in alimentation.

\section{References}

Al-Mamary, M., Molham, A.-H., Abdulwali, A.-A., \& Al-Obeidi, A. (2001). In vivo effects of dietary sorghum tannins on rabbit digestive enzymes and mineral absorption. Nutrition Research, 21(10), 1393-1401.

Alonzo, N., \& Hirs, C. H. W. (1968). Automation of sample application in amino acid analyzers. Analytical Biochemistry, 23(2), 272-288.

Anglani, C. (1998). Sorghum for human food - A review. Plant Foods for Human Nutrition (Formerly Qualitas Plantarum), 52(1), 85-95.

AOAC (2002). Association of official analytical chemists. Official Methods of Analysis of the AOAC International. Gaithersburg, MD, USA: Association of Analytical Communities.

Bender, A. E., \& Doell, B. H. (1957). Note on the determination of net protein utilization by carcass analysis. British Journal of Nutrition, 11(02), 138-139.

Burns, R. E. (1971). Method for estimation of tannin in grain sorghum 1. Agronomy Journal, 63(3), 511-512.

Correia, I., Nunes, A., Barros, A. S., \& Delgadillo, I. (2010). Comparison of the effects induced by different processing methods on sorghum proteins. Journal of Cereal Science, 51(1), 146-151.

Deyoe, C. W., \& Shellenberger, J. A. (1965). Nutritive value of grains, amino acids and proteins in sorghum grain. Journal of Agricultural and Food Chemistry, 13(5), 446-450.
Dicko, M. H., Gruppen, H., Traoré, A. S., Voragen, A. G. J., \& Berkel, W. J. H. (2006) Sorghum grain as human food in Africa: Relevance of content of starch and amylase activities. African Journal of Biotechnology, 5(5), 384-395.

Duodu, K. G., Taylor, J. R. N., Belton, P. S., \& Hamaker, B. R. (2003). Factors affecting sorghum protein digestibility. Journal of Cereal Science, 38(2), 117-131.

Dykes, L., \& Rooney, L. W. (2006). Sorghum and millet phenols and antioxidants. Journal of Cereal Science, 44(3), 236-251.

Dykes, L., Rooney, L. W., Waniska, R. D., \& Rooney, W. L. (2005). Phenolic compounds and antioxidant activity of sorghum grains of varying genotypes. Journal of Agricultural and Food Chemistry, 53(17), 6813-6818.

Emmambux, M. N., \& Taylor, J. R. N. (2009). Properties of heat-treated sorghum and maize meal and their prolamin proteins. Journal of Agricultural and Food Chemistry, 57(3), 1045-1050.

Friedman, M., \& Gumbmann, M. R. (1986). Nutritional improvement of soy flour through inactivation of trypsin inhibitors by sodium sulfite. Journal of Food Science, 51(5), 1239-1241.

Hamaker, B. R., Kirleis, A. W., Mertz, E. T., \& Axtell, J. D. (1986). Effect of cooking on the protein profiles and in vitro digestibility of sorghum and maize. Journal of Agricultural and Food Chemistry, 34(4), 647-649.

Hegsted, D. M. (1977). Protein quality and its determination. In J. H. Whitaker \& S. H. Tannenbauum (Eds.), Foods proteins (pp. 347-362). Westport: AVI Publishing.

Henley, E. C., \& Kuster, J. M. (1994). Protein quality evaluation by protein digestibility corrected amino acid scoring. Food Technology, 4 74-77.

Márquez, O., \& Waliszewski, K. N. (2008). The effect of thermal treatment on $\beta$ glucosidase inactivation in vanilla bean (Vanilla planifolia Andrews). International Journal of Food Science and Technology, 43(11), 1993-1999.

Maxson, E. D., \& Rooney, L. M. (1972). Evaluation of methods for tannin analysis in sorghum grain. Cereal Chemistry, 49, 719-729.

Mendes, F. Q., Oliveira, M. G. d. A., Costa, N. M. B., Pires, C. V., \& Hoffmam, Z. B. (2009). Qualidade protéico de diversos alimentos, incluindo diferentes variedade de soja. Revista Alimentos e Nutrição, 20(1), 77-86.

Méndez-Albores, A., Martínez-Bustos, F., Véles-Medina, J. J., Moreno-Ramos, C., RíoGarcía, J. C. D., \& Moreno-Martínez, E. (2009). Efecto de la adición de ácido cítrico sobre La Degradación de las aflatoxinas y las propiedades Funcionales de productos extrudidos de sorgo. Interciencia, 43(4), 252-258.

Mertz, E. T., Hassen, M. M., Cairns-Whittern, C., Kirleis, A. W., Tu, L., \& Axtell, J. D. (1984). Pepsin digestibility of proteins in sorghum and other major cereals. Proceedings of the National Academy of Sciences of the United States of America, 81(1), 1-2.

Mohammed, N. A., Mohamed, A. I. A., \& Babiker, E. E. (2010). Nutritional evaluation of sorghum flour (Sorghum bicolor (L.) Moench) during processing of injera. International Journal of Biological and Life Sciences, 6(1), 35-39.

Mokrane, H., Amoura, H., Belhaneche-Bensemra, N., Courtin, C. M., Delcour, J. A., \& Nadjemi, B. (2010). Assessment of algerian sorghum protein quality (Sorghum bicolor (L.) Moench) using amino acid analysis and in vitro pepsin digestibility. Food Chemistry, 121(3), 719-723.

Morant, A. V., Jørgensen, K., Jørgensen, C., Paquette, S. M., Sánchez-Pérez, R., Møller B. L., et al. (2008). [beta]-Glucosidases as detonators of plant chemical defense. Phytochemistry, 69(9), 1795-1813.

Onyango, C., Noetzold, H., Bley, T., \& Henle, T. (2004). Proximate composition and digestibility of fermented and extruded uji from maize-finger millet blend. Lebensmittel - Wissenschaft und-Technologie, 37(8), 827-832.

Pires, C. V., Oliveira, M. G. d. A., Rosa, J. C., \& Costa, N. M. B. (2006). Qualidade nutricional e escore químico de aminoácidos de diferentes fontes protéicas. Ciência e Tecnologia de Alimentos, 26, 179-187.

Prates, H. T. Schaffert, R. E. Santos, F. G., Rodrigues, J. A. S., Butler, L, Raslan, D. S. et al. (1998). Isolation, purification, and quantification of dhurrin from tanninfree bird-resistant grain sorghum. International Sorghum and Millets Newsletter 39, 103-104.

Price, M. L., Van Scoyoc, S., \& Butler, L. G. (1978). A critical evaluation of the vanillin reaction as an assay for tannin in sorghum grain. Journal of Agricultural and Food Chemistry, 26(5), 1214-1218. 
Reeves, P. G., Nielsen, F. H., \& Fahey, G. C. (1993). AIN-93 purified diets for laboratory rodents: Final report of the American institute of nutrition ad hoc writing committee on the reformulation of the AIN-76A rodent diet. The Journal of Nutrition, 123(11), 1939-1951.

Sanchez, D. A. (2003). White food-type sorghum in direct-expansion extrusion applications. Food Science and Technology, Master of Science (vol., p. 132). Texas: Texas A\&M University.

Singleton, V. L., Orthofer, R., Lamuela-Raventós, R. M., \& Lester, P. (1999). Analysis of total phenols and other oxidation substrates and antioxidants by means of Folin-Ciocalteu reagent. Methods in Enzymology, (vol. 299, pp. 152-178): Academic Press.
Souza, C. C., Dantas, J. P., Silva, S. d. M., Souza, V. C., Almeida, F. A., \& Silva, L. E. d. (2005). Produtividade do Sorgo granífero cv. sacarino e qualidade de produtos formulados isoladamente ou combinados ao caldo de cana-de-açúcar. Ciência e Tecnologia de Alimentos, 25, 512-517.

Spackman, D. H., Stein, W. H., \& Moore, S. (1958). Automatic recording apparatus for use in chromatography of amino acids. Analytical Chemistry, 30(7), 1190-1206. USDA (2010). National Nutrient Database for Standard Reference, United States Department of Agriculture <http://www.nal.usda.gov/fnic/foodcomp/cgi-bin/ list_nut_edit.pl>.

WHO (2007). Protein and amino acid requirements in human nutrition; report of a joint FAO/WHO/UNU expert consultation WHO Technical Report Series 935. Geneva: WHO. 